\title{
Assessment of Cytotoxicity in Chemotherapeutic Drugs-By Invitro Methods
}

\author{
${ }^{1}$ Dr. Nasir A Salati, ${ }^{2}$ Dr S.S. Ahmad, ${ }^{3}$ Dr. Kauser J Khwaja \\ 1. Assistant Department of Oral Pathology, Professor, Z. A .Dental College, A.M.U., Aligarh \\ 2. Professor, Department of oral surgery, Z. A. Dental College, A.M.U., Aligarh \\ 3. Chairman, Department of Oral Pathology, Z.A.Dental College, A.M.U., Aligarh
}

\begin{abstract}
For past many years, strategies for the preclinical discovery and development of potential anticancer agents have been based largely upon the testing of agents in. selected animals bearing transplantable tumors. The feasibility of implementing combined in vitro/in vivo screening for selective cytotoxicity among panels of human tumor cell lines derived from a broad spectrum of human carcinomas has been evaluated in recent times.. Short-term in vitro drug sensitivity assays have raised the possibility of predicting clinical outcome and selecting optimal components for chemotherapeutic protocols for individual patients. This article discusses various in-vitro methods to access cytotoxicity of different drugs in various cultured malignant tissues.
\end{abstract}

Key Words: Brine shrimp, Cytotoxicity, MTT assay, Subculture, Screening.

\section{Introduction}

Screening involves scanning and evalution of test compound. It always involves a test or a group of tests, which will permit the detection of physiological activities of compound. The chief purpose of screening, are to demonstrate, whether the new group of compounds have useful pharmacological properties. There are different types of screening : ( i) Simple screening: When one or two tests are used to find substances having a particular property, no need a battery of tests in which the results of one test may depend on those of another test. For example: a single test for the concentration of sugar in the blood might be used to screen compounds for hypoglycemic activities. ii) Blind screening: If a new series of chemical substances isolated from natural source or through synthesis. There may be no information on its pharmacological activities, then blind screening is done. (iii) Programmed screening: When a series of compounds is to be investigated for some pharmacological effects, this type of screening is done. Bioassay is defined as the estimation of the potency of an active principle in a unit quantity of preparation or detection and measurement of the concentration of the substance in a preparation using biological methods (i.e. observation of pharmacological effects on living tissues, microorganisms or immune cells or animal).

A battery of cell- and enzyme-based marker systems, have been used for prevention of carcinogenesis in vivo. These systems include modulation of drug metabolism (inhibition of Cyp1A activity, induction of $\mathrm{NAD}(\mathrm{P}) \mathrm{H}$ :quinone reductase (QR) activity in Hepa1c1c7 murine hepatoma cell culture), determination of radical scavenging (DPPH scavenging) and antioxidant effects (scavenging of superoxide anion-, hydroxyl- and peroxyl-radicals), anti-inflammatory mechanisms (inhibition of lipopolysaccharide (LPS)-mediated nitric oxide (NO) generation by inducible NO synthase (iNOS) in Raw 264.7 murine macrophages, cyclooxygenase-1 (Cox1) inhibition), and anti-tumor promoting activities (inhibition of phorbol ester-induced ornithine decarboxylase (ODC) activity in 308 murine keratinocytes). ${ }^{1}$ In vitro methods have been largely used nowadays in screening of anti-cancer drugs, because of certain advantages over in vivo methods. In Vitro methods are less expensive, less time consuming, less complicated, mostly reproducible, $\&$ no requirement of any living person or animal. ${ }^{2}$ Important methods used to assess cytotoxicity are: Brine Shrimp Lethality bioassay, MTT assay, Sulporhodamine assay, Trypan blue dye exclusion assay, Acridine orange/Ethidium Bromide staining $\&$ DNA fragmentation assay.

\section{Cell Culture Assays ${ }^{4,5}$}

Maintainence of cell lines: HeLa (human epithelial cervical carcinoma) and MCF-7 (human breast adenocarcinoma) cells procured from diseased tissues. These are grown in $25 \mathrm{~cm}^{2}$ tissue culture flasks containing suitable media. ${ }^{3}$ These cells are maintained by using Dulbecco's Minimum Essential Medium (DMEM) supplemented with $10 \% \mathrm{FBS}, 1 \%$ Penicillin Streptomycin at $37^{\circ} \mathrm{C}$ in $\mathrm{CO}_{2}$ incubator. Sub culturing is done in $25 \mathrm{~cm}^{2}$ tissue culture flasks, and cells are studied. Sub- culturing process of cell lines is done by a method called trypsinization. Here, cells are dislodged from the culture flasks by various techniques. The culture media from the flasks containing monolayer culture is aspirated and washed with sterile phosphate buffered saline (PBS). Subsequently, $2 \mathrm{~mL}$ of $0.1 \%$ trypsin-EDTA solution is added \& flask is kept in incubator for $2-3$ 
min. This allows the cells to be detached. The flask is taken from the incubator and the cell detachment is confirmed by observing under an inverted microscope. Once the cells are completely detached from the flasks, 3 $\mathrm{mL}$ of DMEM media containing 10\% FBS is added and mixed well.

Cell viability is checked with a small sample of the suspension by trypan blue dye exclusion test. This method is used to obtain a single cell suspension from a monolayer culture.

Preservation of the tumor cells: Tumor cells from the first and second passage of transplantation are stored in liquid nitrogen in cryovials containing media supplemented with $20 \%$ serum and $10 \%$ DMSO as preservative at a concentration of $10^{6}$ cells $/ \mathrm{mL}$. This constitutes the tumor bank. After every 10 passages, that tumor cell line is discarded and new passage is started using the original tumor cells from the tumor bank.

\section{Brine Shrimp Lethality Assay}

Principle: A method utilising brine shrimp (Artemia salina), is a simple bioassay for natural product research. The procedure determines lethal concentrations of active compounds in brine medium. The activities of a broad range of active compounds are manifested as toxicity to the shrimp. The method is rapid, reliable and has been used for over thirty years in toxicological studies. A positive correlation exists between brine shrimp lethality and human carcinoma.

Hatching chamber: It is made of glass, with aluminum lid on top. The chamber is divided into two equal parts with the help of a laminated plywood divider having a number of holes of $2 \mathrm{~mm}$ size. One of the compartments is illuminated with a lamp (60 watts), while the other is darkened. Both the chambers are aerated.

Drug sample preparation: Samples of the drug are prepared by dissolving $5 \mathrm{mg}$ of drug in $10 \mathrm{ml}$ of DMSO to get $500 \mu \mathrm{M}$ stock solution. From this stock final drug concentration are prepared and volume is made up to $5 \mathrm{ml}$ (in $7 \mathrm{ml}$ vial capacity) with solution which contain specific volume of brine and yeast suspension to get the final drug conc. Three replicates were prepared for each dose level. Control vials are prepared by adding equal volumes of distilled water.

Bioassay Method: The 5.0L of artificial sea water is added to the special chamber $0.20 \mathrm{mg}$ of the eggs are washed with water and then these eggs are sprinkled into the compartment which is darkened. Aeration is provided in compartments. After $48 \mathrm{hrs}$, the phototropic nauplli are collected and are used for bioassay. Nauplli are drawn in a pipette along with water, and ten of such shrimps are transferred to each sample vial after they are counted in the stem of pipette against lighted background. The artificial sea water is added to each vial to make upto $5 \mathrm{ml}$. A drop of dry yeast suspension $(3 \mathrm{mg}$ in $5-\mathrm{ml}$ sea water) is added to each vial as food for shrimps. The vials are maintained under illumination. After $24 \mathrm{hrs}$, survivors are counted by using $3 \mathrm{X}$ magnifying glass, and the percent deaths and $\mathrm{LD}_{50}$ values are calculated.

\section{MTT assay}

Principle: Succinate-tetrazolium reductase system belongs to the mitochondrial respiratory chain functioning in metabolically active cells. MTT, [3-(4, 5-dimethylthiazol-2-yl)-2, 5-diphenyltetrazolium bromide], is reduced to formazan by viable cells with the help of "Succinate-tetrazolium reductase" system. Formazan is largely impermeable to cell membranes, thus resulting in its accumulation within the healthy cells. Dimethyl sulphoxide (DMSO) on reacting with formazan gives purplish color. The optical density (OD) of purple colored solution developed is read using a conventional ELISA plate reader at 590nm (maximum absorbance). This ability of cells to reduce MTT provides an indication of the mitochondrial integrity and activity, interpreted as a measure of quantitative assessment and viability of cells.

Reagents and Materials used in this assay are:

- $\quad$ Fetal bovine serum (FBS) and

- DMEM (Dulbecco's Minimum Essential Media)

- $\quad$ MTT reagent

- Tissue culture flasks, 96 well Microculture plates

- $\quad$ Penicillin, Streptomycin

Bioassay method: Exponentially growing HeLa cells are harvested from $25 \mathrm{~cm}^{2}$ tissue culture flasks and a stock cell suspension $10^{5} \mathrm{cell} / \mathrm{mL}$ ) is prepared with media. A 96-well flat bottom tissue culture plate is seeded with $1 \times 10^{4}$ cells in $0.1 \mathrm{~mL}$ of suitable media supplemented with $10 \%$ serum and allowed to attach for $24 \mathrm{hrs}$. Test compounds are prepared just prior to the experiment in $0.1 \%$ DMSO and serially diluted with suitable medium to get the different concentrations of 12.5, 25, 50, 100 and $200 \mu \mathrm{g} / \mathrm{mL}$. After $24 \mathrm{hrs}$ of incubation, cells are treated with $100 \mu \mathrm{L}$ of test compounds from respective concentrations and the plates are again incubated for 48 hours. The cells in the control group received only the medium containing the $0.1 \%$ DMSO (vehicle). Each treatment is performed in triplicates. After the treatment, drug containing media is removed and washed with 200 $\mu \mathrm{L}$ of PBS. To each well of the 96 well plate, $20 \mu \mathrm{L}$ of MTT reagent (Stock: $5 \mathrm{mg} / \mathrm{mL}$ in PBS) is added and incubated for $4 \mathrm{~h}$ at $37^{\circ} \mathrm{C}$. After $4 \mathrm{hrs}$ of incubation the plate is inverted on tissue paper to remove the MTT reagent. 
The optical density (O.D) is measured by an Enzyme Linked Immunosorbent Assay (ELISA) plate reader at 540 nm.

Percent cytotoxicity $=[($ AbsControl-AbsBlank $)-($ AbsTest-AbsBlank $) /($ AbsControl-AbsBlank $)] X$ 100 $)$

\section{Determination of Total Cell Protein Content by Sulphorhodamine B (Srb)}

Principle: SRB is a bright pink aminoxanthene dye with two sulfonic groups. Under mild acidic conditions, SRB binds to protein basic amino acid residues in TCA (Trichloro acetic acid) fixed cells to provide a sensitive index of cellular protein content. Color development in SRB assay is rapid, stable and visible. The developed color can be measured over a broad range of visible wavelength in either spectrophotometer or an ELISA plate reader. When TCA-fixed and SRB stained samples are air-dried, they can be stored indefinitely without deterioration.

Reagents: The reagents used in this assay are:

- $\quad$ SRB dye $(0.054 \%$ prepared in $1 \%$ acetic acid)

- $10 \mathrm{mM}$ TRIS base

- $\quad 50 \%$ TCA (Trichloro acetic acid)

- $\quad$ Microplate reader (ELISA Reader)

Procedure: Cells are seeded onto 96-well microtiter plates at a concentration of $\left(1 \mathrm{X} 10^{5} \mathrm{cell} / \mathrm{mL}\right)$. The plates are incubated at $36.5^{\circ} \mathrm{C}$ in humidified $\mathrm{CO}_{2}(10 \%)$ incubator for $24 \mathrm{hr}$. About $10 \mu \mathrm{L}$ of test compound is added to these plates. Plates are incubated for next $48-72 \mathrm{hr}$ at $36.5^{\circ} \mathrm{C}$ in humidified $\mathrm{CO}_{2}(10 \%)$ incubator. After incubation medium is removed for the wells and $200 \mu \mathrm{L}$ of $10 \%$ TCA is added. After 30 minutes, plates are washed gently under tap water and air dried at room temperature. Then $100 \mu \mathrm{L}$ SRB reagent is added into each well and left for 15 minutes. $1 \%$ acetic acid is used to remove SRB. After air drying, $0.2 \mathrm{ml}$ of $10 \mathrm{mM}$ unbuffered TRIS base is added, and absorbance is measured at $540 \mathrm{~nm}$.

$\mathrm{ED}_{50}$ value of compounds possessed cytotoxic activity is calculated by following formula:

\section{Percentage growth inhibition $=100-($ AbsTest $/$ AbsControl $) X 100$}

\section{Trypan Blue Dye Exclusion Assay}

Principle: It is a short-term in vitro screening system for test compounds. A living cell membrane has the ability to prevent the entry of certain dyes into the cell. Hence, the viable cells remain unstained and can be easily distinguished from the dead cells that take up the dye and appear blue under the microscope. Cell lines like, MCF-7 (Human breast adenocarcinoma cells, ER positive), EAC (Ehlrich's ascitic carcnoma) are used.

Procedure: Ascitic fluid withdrawn from the peritoneum of EAC inoculated animals is washed with PBS. The stock cell suspension of $1 \times 10^{7}$ is made with PBS from which $0.1 \mathrm{ml}$ of suspension is taken in sterile test tubes. The cells are treated with $0.1 \mathrm{ml}$ of drug solution of varying concentrations and $0.7 \mathrm{ml}$ of PBS was added. The cells are incubated at $37^{\circ} \mathrm{C}$ for $3 \mathrm{hrs}$. After the exposure $0.1 \mathrm{ml}$ of trypan blue is added and mixed well. The total number of dead and living cells in all the four corner squares of the chambers are counted using haemocytometer.

Percentage viability/cytotoxicity is done by comparing number of unstained cells with total number of cells.

\section{Acridine Orange/Ethidium Bromide Staining (Ao/Eb Staining)}

Principle: Chromatin condensation and nuclear fragmentation remain the hallmarks of apoptotic cells. For morphological examination of the cells, fluorescent DNA binding dyes (such as AO/EB staining) is a method of choice. Acridines orange (AO) permeates all cells and makes the nuclei appear green. Ethidium bromide (EB) is only taken up by cells when cytoplasmic membrane integrity is lost, and stains the nucleus red. Live cell show green color, whereas early apoptotic cells show bright green (condensed or fragmented chromatin). Late apoptotic cells are colored orange chromatin.

Cell lines: MCF-7 (Human breast adenocarcinoma cells)

Reagents:

- $1 \mathrm{mg}$ Ethidium bromide dissolved in $1 \mathrm{~mL}$ milli-equivalent water

- $1 \mathrm{mg}$ Acridine orange dissolved in $1 \mathrm{~mL}$ meq water

Procedure: MCF-7 cells $\left(1 \mathrm{X} 10^{6}\right)$ are seeded in T-25 flask in $5 \mathrm{~mL}$ of DMEM (Dulbecoo's modified eagle's medium) supplemented with 10\% FBS and allowed to attach for 24h.Then the petroleum ether, ethyl acetate, butanolic and alcoholic extracts are added at their IC50 (determined from SRB assay) to the flasks, and the flasks are kept in incubator for $48 \mathrm{hrs}$ at $37^{\circ} \mathrm{c}$. Media containing floating cells is removed into centrifuge tubes and centrifuged at $1000 \mathrm{rpm}$ for $5 \mathrm{~min}$. Cells are washed with PBS and stored at $4^{\circ} \mathrm{C}$ in ethanol. To $20 \mu \mathrm{l}$ of the cell suspensions, $5 \mu$ of ethidium bromide and $5 \mu \mathrm{l}$ of acridine orange solutions are added and kept for 5 minutes.

A small aliquot of this solution is placed on a slide and observed under the fluorescent microscope (blue filter). 


\section{D NA Fragmentation Assay}

Principle: Apoptosis is a distinct mode of cell death that is responsible for death of cells in normal and pathologic state, involves changes such as blebbing, cell membrane changes such as loss of membrane asymmetry and attachment, cell shrinkage, nuclear fragmentation, chromatin condensation, and chromosomal DNA fragmentation. A DNA ladder represents a band of DNA molecules of varying lengths separated in agarose gel by electrophoresis, migration speed of DNA molecule through gel (which acts as sieve) depends upon its mass, (molecular weight) where smaller DNA fragments migrate rapidly compared to larger ones.

\section{Reagents:}

- Lysis buffer $(1 \mathrm{~mL}$ stock contains $10 \% \mathrm{NP}-40[100 \mu \mathrm{l}]+200 \mathrm{mM}$ EDTA $[40 \mu \mathrm{l}]+0.2 \mathrm{M}$ Tris- $\mathrm{HCl}[50$ $\mu \mathrm{l} ; \mathrm{pH} 7.5]+0.5 \mathrm{mg}$ Proteinase $\mathrm{K}+810 \mu \mathrm{l}$ Milli-Q H2O)

- RNAse solution $(1 \mathrm{mg} / \mathrm{mL})$

\section{TBE buffer composition:}

TRIZMA base - $54 \mathrm{gms}$

Boric acid - 25.1gms

0.5M EDTA solution - $20 \mathrm{~mL}$

Procedure: MCF-7 cells $\left(1 \mathrm{X} 10^{6}\right)$ are seeded in T-25 flask in $5 \mathrm{~mL}$ of DMEM medium supplemented with 10\% FBS and allowed to attach for 24h.The petroleum ether, ethyl acetate, butanolic and ethanolic extracts are added at their IC50 (determined from SRB assay) to the flasks and the flasks are kept in incubator for $48 \mathrm{hrs}$ at $37^{\circ} \mathrm{C}$. Media containing floating cells is removed into centrifuge tubes and centrifuged at $1000 \mathrm{rpm}$ for $5 \mathrm{~min} .300 \mu \mathrm{l}$ of lysis buffer is added to flask containing attached cells monolayer. The cells are scraped and added to the cell pellet in the tubes obtained after centrifugation. The cells pellet in lysis buffer is incubated at $50{ }^{\circ} \mathrm{C}$ for $1 \mathrm{~h}$, followed by addition of RNAse solution. After that cells again kept at $50{ }^{\circ} \mathrm{C}$ or $1 \mathrm{~h}$. A brief exposure at $65{ }^{\circ} \mathrm{C}$ for $2 \mathrm{~min}$ is followed to destroy the RNA. The processed cells are then cooled at room temperature, diluted with $30 \%$ glycerol in the ratio1:1 and loaded into the wells of agarose gel (1.5\% in TBE buffer). Electrophoresis is carried by using Bio-Rad electrophoresis unit out at $60 \mathrm{~V}, 400 \mathrm{~mA}$ for $180 \mathrm{~min}$ using TBE buffer.

\section{Conclusion}

We have discussed various in-vitro screening methods used in assessment of cytotoxicity of different chemotherapeutic drugs. The advantages of in-vitro methods over in-vitro methods demand more research in near future.

\section{Acknowledgements}

My thanks to Dr Raghu AR, Head of Department, Department of Oral Pathology, MCODS, Manipal for his support and encouragement.

\section{Journal Papers:}

\section{References}

[1]. Gerhäuser C, Klimo K, Heiss E, Neumann I, Gamal-Eldeen A, Knauft J, Liu GY, Sitthimonchai S, Frank N Mechanism-based in vitro screening of potential cancer chemopreventive agents. Mutat Res. 2003 Feb-Mar;523-524:163-72.

[2]. Ames B.N, Gold L.S, Willett W C. The causes and prevention of cancer Proceedings of the National Academy of Sciences. 1995; 92 (12): 5258-65.

[3]. Syrovy L and Hodny Z (1991): Staining and quantification of proteins separated by Poly Acrylamide Gel Electrophoresis. Journal of Chromatography, 569: 175-96.

BOOKS:

[4]. Mohammad Azam, Rational Drug Design : Methods and Protocols Series: Methods in Molecular Biology Volume: 928 Sep-032012 Page Range: 175-184

\section{CHAPTERS IN BOOKS:}

[5]. [5]. Atta ur Rahman, M Iqbal choudary \& William Johnson. Anti viral \& anti cancer screening. Bio assay technique for drug development .2001.Ch: 1.3. pp :27-36 